\title{
Assessment of chemical, biochemical and ecotoxicological aspects in a mine soil amended with sludge of either urban or industrial origin
}

\author{
P. Alvarenga ${ }^{\mathrm{a}, *}$, P. Palma ${ }^{\mathrm{a}}$, A.P. Gonçalves ${ }^{\mathrm{a}}$, N. Baião ${ }^{\mathrm{a}}$, R.M. Fernandes ${ }^{\mathrm{a}}$, A. de Varennes ${ }^{\mathrm{b}}$, G. Vallini $^{\mathrm{c}}$, \\ E. Duarte ${ }^{\text {b }}$, A.C. Cunha-Queda ${ }^{\text {b }}$ \\ ${ }^{a}$ Department of Environmental Sciences, Escola Superior Agrária de Beja, Rua Pedro Soares, Apartado 6158, 7801-908 Beja, Portugal

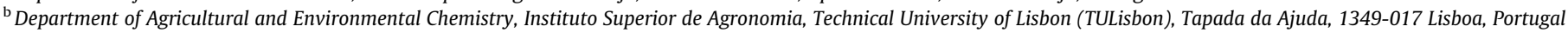 \\ ' Department of Science and Technology, Laboratories of Microbial Biotechnology and Environmental Microbiology, University of Verona - Strada Le Grazie 15, Ca' Vignal, 37134 \\ Verona, Italy
}

\section{A R T I C L E I N F O}

\section{Article history:}

Received 18 January 2008

Received in revised form 14 April 2008

Accepted 15 April 2008

Available online 10 June 2008

\section{Keywords:}

Mine contaminated soil

Soil remediation

Sewage sludge

Bioavailability

Enzymatic activities

Ecotoxicity

\begin{abstract}
A B S T R A C T
A greenhouse pot experiment was conducted to evaluate the effect of sewage sludge (SS), of sugar beet sludge (SBS), or of a combination of both, in the remediation of a highly acidic ( $\mathrm{pH} 3.6$ ) metal-contaminated soil, affected by mining activities. The SS was applied at 100 and $200 \mathrm{Mg} \mathrm{ha}^{-1}$ (dry weight basis), and the SBS at $7 \mathrm{Mg} \mathrm{ha}^{-1}$. All pots were sown with Italian ryegrass (Lolium multiflorum Lam.). After $60 \mathrm{~d}$ of growth, shoot biomass was quantified and analysed for $\mathrm{Cu}, \mathrm{Pb}$ and $\mathrm{Zn}$. The pseudo-total and bioavailable contents of $\mathrm{Cu}, \mathrm{Pb}$ and $\mathrm{Zn}$ and the enzymatic activities of $\beta$-glucosidase, acid phosphatase, cellulase, protease and urease were determined in the soil mixtures. Two indirect acute bioassays with leachates from the soil (luminescent inhibition of Vibrio fischeri and Daphnia magna immobilization) were also used.

The SS, in particular when in combination with SBS, corrected soil acidity, while increasing the total organic matter content and the cation exchange capacity. The application of SS led to a decrease in the level of effective bioavailable metals (extracted by $0.01 \mathrm{M} \mathrm{CaCl}_{2}, \mathrm{pH} 5.7$, without buffer), but caused an increase in their potential bioavailability (extracted by a solution of $0.5 \mathrm{M} \mathrm{NH}_{4} \mathrm{CH}_{3} \mathrm{COO}, 0.5 \mathrm{M} \mathrm{CH} \mathrm{COOH}$ and 0.01 M EDTA, pH 4.7). Plant biomass increased more than 10 times in the presence of $100 \mathrm{Mg} \mathrm{SS} \mathrm{ha}^{-1}$ and more than five times with the combined use of $100 \mathrm{Mg} \mathrm{SS} \mathrm{ha}^{-1}$ and SBS, but a considerable phytotoxic effect was observed for the application rate of $200 \mathrm{Mg} \mathrm{SS} \mathrm{ha}^{-1}$. Copper, $\mathrm{Pb}$ and $\mathrm{Zn}$ concentrations in the shoots of $L$. multiflorum decreased significantly when using $100 \mathrm{Mg} \mathrm{SS} \mathrm{ha}^{-1}$ or SBS. The activities of $\beta$-glucosidase, urease and protease increased with increasing SS applications rates, but cellulase had a reduced activity when using $200 \mathrm{Mg} \mathrm{ha}^{-1} \mathrm{SS}$. Both amendments were able to suppress soil toxicity to levels that did not affect $D$. magna, but increased the soil leachate toxicity towards $V$. fischeri, especially with the application of $200 \mathrm{Mg} \mathrm{SS} \mathrm{ha}^{-1}$. This study showed that for this type of mine soils, and when using SS of similar composition, the maximum SS application rate should be $100 \mathrm{Mg} \mathrm{ha}^{-1}$, and that liming the SS amended soil with SBS did not contribute to a further improvement in soil quality.
\end{abstract}

(c) 2008 Elsevier Ltd. All rights reserved.

\section{Introduction}

Conventional remedial approaches to metal-contaminated soils involve removal and replacement of soil with clean materials or capping the soil with an impermeable layer to reduce exposure to contaminants (Brown et al., 2005). Rehabilitation projects for abandoned mine lands in Portugal rely on that kind of approach (Matos and Martins, 2006), although it is not considered the most economically or environmentally sound solution available. Alternative remedial technologies are currently being developed which involve leaving the contaminated materials in place and using soil

\footnotetext{
* Corresponding author. Tel.: +351 284314312; fax: +351 284314388

E-mail address: paula.alvarenga@esab.ipbeja.pt (P. Alvarenga).
}

amendments to reduce their bioavailability (Basta et al., 2001; Brown et al., 2003). One example is the use of organic biodegradable residues and limestone, or other materials rich in carbonates, to reduce the bioavailability of contaminants and restore the ecological function of metal-contaminated sites (Basta et al., 2001; Brown et al., 2003). Organic biodegradable residues may be able to improve physical, chemical and biological properties of soils by: (i) raising the $\mathrm{pH}$, (ii) increasing the organic matter content, (iii) adding essential nutrients for plant growth, (iv) increasing the water holding capacity, and (v) rendering the heavy metals less bioavailable. Furthermore, in situ immobilization of metals can be combined with phytostabilization, a vegetation cover that reduces wind erosion and water percolation (Vangronsveld et al., 1995). 
The overall improvement in soil quality should be evaluated based not only on soil chemical characteristics, assessed by conventional analytical tests and extraction procedures, but also on additional assays that measure restoration of habitat functions (Brown et al., 2003, 2005; ISO/DIS 17402, 2006). In fact, chemical analysis is insufficient to evaluate potential ecological risks, since the combined effects of the different contaminants are not taken into consideration. The bioavailability of contaminants should also be examined including a range of ecological receptors and relevant pathways (Brown et al., 2005; ISO/DIS 17402, 2006; Alvarenga et al., 2008).

Ecotoxicity assays can overcome these constraints and are recommended for a complete assessment of soil quality (Conder et al., 2001; van Gestel et al., 2001). Bioassays with vascular plants are versatile tools to assess soil contamination, allowing the identification of the effect of pollutants present in the soil as well as the success of remediation processes (van Gestel et al., 2001).

Ecotoxicological tests using aqueous soil extracts, also called leachates or elutriates, can also be used to assess soil quality. They are based on the assumption that soil organisms are affected by chemical compounds present in the aqueous phase. These bioassays (e.g. using the water flea Daphnia magna and the marine luminescent bacterium Vibrio fischeri) were previously developed to evaluate toxicity in waters, but they can be adapted and used with soil leachates (van Gestel et al., 2001; Loureiro et al., 2005).

Biochemical properties, related to the biocycles of $\mathrm{C}, \mathrm{N}, \mathrm{P}$ and $\mathrm{S}$, can also be used to diagnose soil quality. These include the activities of dehydrogenase and hydrolytic enzymes, such as phosphatase, urease and $\beta$-glucosidase (Gil-Sotres et al., 2005). The enzymes selected should represent a range of processes involved in organic matter decomposition and nutrient cycling or reflect microbial activity.

The aim of this study was to evaluate sewage sludge (SS) from an urban wastewater treatment plant, and sugar beet sludge (SBS), an alkaline sludge resulting from the sugar manufacturing process, or a combination of both, as amendments for the reclamation of a degraded metal-rich mine soil. The improvement in soil quality was assessed by the combined use of chemical, biochemical and ecotoxicological indexes.

\section{Materials and methods}

\subsection{Soil characterization}

Topsoil (<20 cm depth) from a metal-contaminated site in the Aljustrel mining area (a pyrite mine located in SW Portugal in the Iberian Pyrite Belt) was collected in March 2006. A soil subsample was air-dried, passed through a $2-\mathrm{mm}$ sieve and subjected to chemical characterization. Particle-size distribution was determined by the pipet method (Gee and Bauder, 1986). Soil pH $\left(\mathrm{H}_{2} \mathrm{O}\right)$ was determined in a soil to deionised water suspension of $1: 2.5(\mathrm{w} / \mathrm{v})$, and electrical conductivity (EC) in a soil to deionised water suspension of 1:5 (w/v). Total oxidizable organic carbon $\left(C_{\text {org }}\right.$ ) was determined according to Walkley and Black (1934). Soil cation exchange capacity (CEC) was determined using the ammonium acetate ( $\mathrm{pH} 7$ ) method (Sumner and Miller, 1996). Available $\mathrm{P}$ and $\mathrm{K}$ were determined using the Egner-Riehm method (Riehm, 1958). All measurements, except particle-size distribution, were carried out in triplicate. Pseudo-total metal $(\mathrm{Cd}, \mathrm{Cr}, \mathrm{Cu}, \mathrm{Ni}, \mathrm{Pb}$ and $\mathrm{Zn}$ ) concentrations were determined by either flame or electrothermal atomic absorption spectrometry after digestion of the samples with aqua regia according to ISO 11466 (1995), using a Varian apparatus (SpectrAA 220FS, 220Z, and 110Z). Three independent replicates were performed for each sample and blanks were measured in parallel.
The soil used was a sandy loam, highly acidic, low in organic matter (OM) content, in essential nutrients ( $\mathrm{N}, \mathrm{P}$ and $\mathrm{K}$ ) and in CEC (Table 1). The total concentrations of $\mathrm{Cu}, \mathrm{Pb}$ and $\mathrm{Zn}$ present in the soil were high and they exceeded many times their limit value in agriculture soils for SS application allowed by Portuguese Legislation (Decreto-Lei $\left.n^{\circ} 118 / 2006\right)$. However, the referred metals were mostly structurally bound and, therefore, scarcely bioavailable, as discussed elsewhere (Alvarenga et al., 2008).

\subsection{Characterization of organic and inorganic amendments}

The residues tested as soil amendments were an anaerobically digested SS, from an urban wastewater treatment plant located in Portalegre (Portugal), and SBS, an industrial wastewater treatment sludge, resulting from the sugar manufacturing process of a plant located in Coruche (Portugal). The SS was chosen due to its high organic matter content and the SBS due to its liming capacity, since it consisted mostly of $\mathrm{CaCO}_{3}$ (80-85\% dry weight).

Three replicates of each sample were analysed using methodologies previously described by Alvarenga et al. (2007): $\mathrm{pH}$ and EC were measured in a suspension with a residue/water ratio of $1: 5$ $(\mathrm{w} / \mathrm{v})$, after $1 \mathrm{~h}$ stirring. OM was determined by loss on ignition at $550{ }^{\circ} \mathrm{C}$ for $8 \mathrm{~h}$. Total nitrogen was analysed using the Kjeldahl method and total phosphorous was measured colorimetrically as molybdo-vanadate phosphoric acid. Calcium and $\mathrm{Mg}$ were analysed spectrometrically by atomic absorption, using a VARIAN apparatus (SpectrAA 220FS) after digestion of the samples with $3 \mathrm{M} \mathrm{HCl}$. This same digested solution was analysed for $\mathrm{Na}$ and $\mathrm{K}$ by flame photometry (Corning Flame Photometer 410). Total heavy metal content $(\mathrm{Cd}, \mathrm{Cr}, \mathrm{Cu}, \mathrm{Ni}, \mathrm{Pb}$ and $\mathrm{Zn})$ was determined as described above for the soil characterization. All these parameters were determined on dry samples (approximately 95\% dry matter content for both sludges), as they were used in the soil amendment. All analytical results were corrected to dry matter basis.

Both sludges had total metal contents below the established limits for SS (Decreto-Lei $\left.n^{\circ} 118 / 2006\right)$, allowing their use in agricultural soils.
Table 1

Characteristics of the soil and of the sewage sludge (SS) and sugar beet sludge (SBS) used in the study (range values or mean \pm standard deviation, $n=3$ )

\begin{tabular}{|c|c|c|c|}
\hline Parameter & Soil & SS & SBS \\
\hline $\mathrm{pH}$ & $3.4-3.8$ & $6.5-6.8$ & $8.3-8.9$ \\
\hline $\mathrm{EC}\left(\mathrm{dS} \mathrm{m}^{-1}\right)$ & $0.207 \pm 0.07$ & $2.90 \pm 0.09$ & $1.33 \pm 0.08$ \\
\hline Organic matter (\% DW) & $0.37 \pm 0.02$ & $72 \pm 2$ & $11.6 \pm 2.7$ \\
\hline $\mathrm{CEC}\left(\mathrm{cmol} \mathrm{kg}^{-1}\right)$ & $5.6 \pm 0.5$ & - & - \\
\hline \multicolumn{4}{|l|}{ Texture $\left(\mathrm{g} \mathrm{kg}^{-1}\right)$} \\
\hline Sand & 704 & - & - \\
\hline Silt & 177 & - & - \\
\hline Clay & 119 & - & - \\
\hline $\mathrm{N}_{\text {Kjeldahl }}(\% \mathrm{DW})$ & $0.07 \pm 0.1$ & $7.2 \pm 0.4$ & $0.37 \pm 0.08$ \\
\hline Extractable-P (mg kg $\left.{ }^{-1} \mathrm{DW}\right)$ & n.d. & - & - \\
\hline Extractable-K (mg kg $\left.{ }^{-1} \mathrm{DW}\right)$ & $52 \pm 2$ & - & - \\
\hline Total P (\% DW) & - & $1.36 \pm 0.06$ & $0.6 \pm 0.2$ \\
\hline $\mathrm{Na}\left(\mathrm{g} \mathrm{kg}^{-1} \mathrm{DW}\right)$ & - & $4.6 \pm 0.9$ & $0.75 \pm 0.07$ \\
\hline $\mathrm{K}\left(\mathrm{g} \mathrm{kg}^{-1} \mathrm{DW}\right)$ & - & $1.3 \pm 0.3$ & $0.21 \pm 0.05$ \\
\hline $\mathrm{Ca}\left(\mathrm{g} \mathrm{kg}^{-1} \mathrm{DW}\right)$ & - & $21.7 \pm 0.8$ & $345 \pm 22$ \\
\hline $\operatorname{Mg}\left(\mathrm{g} \mathrm{kg}^{-1} \mathrm{DW}\right)$ & - & $3.4 \pm 0.2$ & $9.3 \pm 0.7$ \\
\hline $\mathrm{Cd}\left(\mathrm{mg} \mathrm{kg}^{-1} \mathrm{DW}\right)$ & $2.6 \pm 0.2$ & $1.46 \pm 0.04$ & $<0.5$ \\
\hline $\mathrm{Cr}\left(\mathrm{mg} \mathrm{kg}^{-1} \mathrm{DW}\right)$ & $21.8 \pm 0.6$ & $15.3 \pm 0.2$ & $6.4 \pm 0.2$ \\
\hline $\mathrm{Cu}\left(\mathrm{mg} \mathrm{kg}^{-1} \mathrm{DW}\right)$ & $362 \pm 23$ & $98 \pm 5$ & $27 \pm 8$ \\
\hline $\mathrm{Ni}\left(\mathrm{mg} \mathrm{kg}^{-1} \mathrm{DW}\right)$ & $15.4 \pm 0.4$ & $10.0 \pm 0.1$ & $<1$ \\
\hline $\mathrm{Pb}\left(\mathrm{mg} \mathrm{kg}^{-1} \mathrm{DW}\right)$ & $4350 \pm 169$ & $37 \pm 1$ & $12 \pm 2$ \\
\hline $\mathrm{Zn}\left(\mathrm{mg} \mathrm{kg}^{-1} \mathrm{DW}\right)$ & $245 \pm 64$ & $491 \pm 12$ & $51 \pm 4$ \\
\hline
\end{tabular}

DW: dry weight; EC: electrical conductivity; CEC: cation exchange capacity; n.d.: not detected. 


\subsection{Experimental set-up}

The soil was homogenised, without sieving, and stored at field moisture content. Pots were prepared with $3000 \pm 100 \mathrm{~g}$ of soil (dry weight basis), plus the amendments. The SS was applied at 100 and $200 \mathrm{Mg} \mathrm{ha}^{-1}$ (51 and $102 \mathrm{~g} \mathrm{~kg}^{-1}$, respectively, dry weight basis), and the SBS at $7 \mathrm{Mg} \mathrm{ha}^{-1}\left(4 \mathrm{~g} \mathrm{~kg}^{-1}\right.$, based on its neutralizing value and soil buffer capacity). The amendments were tested alone, or in combination. A control, which did not receive any amendment, was included in the study. The soil mixtures were then adjusted to $70 \%$ of their maximum water holding capacity, with deionised water, transferred to a greenhouse, and allowed to equilibrate for $28 \mathrm{~d}$ prior to sowing. The experiment had a completely randomised design, with three replicates per treatment. After the incubation period, Italian ryegrass (Lolium multiflorum Lam.) was sown ( $2 \mathrm{~g}$ of seeds in each pot), and allowed to grow for $60 \mathrm{~d}$. The pots were daily watered, throughout the experiment to maintain their initial water content.

\subsection{Plant analysis}

At harvest, the shoots were removed from the pots, washed thoroughly with tap water to remove any attached particles, and then rinsed three times with deionised water. The samples were dried at $70^{\circ} \mathrm{C}$ for $48 \mathrm{~h}$, weighed, and ground in an electric mill. Approximately $1 \mathrm{~g}$ of dried plant sample was ashed in a muffle furnace at $500{ }^{\circ} \mathrm{C}$ for $6 \mathrm{~h}$, dissolved with $10 \mathrm{~mL}$ of $3 \mathrm{M} \mathrm{HCl}$ and evaporated to near dryness twice, dissolved again with the same acid solution, filtered (blue ribbon filter 589/3, Schleicher and Schuell Filters), and adjusted to a volume of $100 \mathrm{~mL}$ with ultra-pure water. The samples were analysed for total $\mathrm{Cu}, \mathrm{Pb}$ and $\mathrm{Zn}$, by flame atomic absorption spectrometry, using a Varian apparatus (SpectrAA 220FS).

\subsection{Soil characterization after remediation}

\subsubsection{Chemical analysis}

The soil mixtures were air-dried, passed through a $2 \mathrm{~mm}$ sieve and analysed as described before.

Metal bioavailable fractions were determined using two different single step extractions: a mobile fraction (extracted by $0.01 \mathrm{M}$ $\mathrm{CaCl}_{2}, \mathrm{pH}$ 5.7, without buffer), sometimes referred as the "effective bioavailable metal fraction", and a mobilisable fraction (extracted by a solution of $0.5 \mathrm{M} \mathrm{NH}_{4} \mathrm{CH}_{3} \mathrm{COO}, 0.5 \mathrm{M} \mathrm{CH}_{3} \mathrm{COOH}$ and $0.01 \mathrm{M}$ EDTA, pH 4.7), considered as a "potentially bioavailable metal fraction” (Alvarenga et al., 2008). Extractions were performed with $2 \mathrm{~h}$ horizontal reciprocate shaking, on a 1:10 (w/v) soil to solution ratio, at room temperature. The extract was separated from the solid residue by centrifugation at $3000 \mathrm{~g}$ for $10 \mathrm{~min}$.

\subsubsection{Enzymatic activities}

Soil sub-samples were kept refrigerated $\left(4^{\circ} \mathrm{C}\right)$ at their "field moisture content". Before analysis, samples were sieved through a $2 \mathrm{~mm}$ sieve, and their dry matter content was determined to express the enzymatic activity on a dry matter basis.

Acid phosphomonoesterase (EC 3.1.3.2) and $\beta$-glucosidase (EC 3.2.1.21) activities were measured by incubating the soil with a substrate containing a $p$-nitrophenyl group in its structure, according to Eivazi and Tabatabai $(1977,1988)$. Cellulase activity was determined according to Hope and Burns (1987). Cellulases are enzyme systems that degrade cellulose and release reducing sugars as the end product. In the context of this work, the term refers to the combined action of endo-1,4- $\beta$-D-glucanase (EC 3.2.1.4), exo1,4- $\beta$-D-glucanase (EC 3.2.1.91) and $\beta$-D-glucosidase (EC 3.2.1.21) on Avicel, a purified depolymerised alpha cellulose. Urease (EC 3.5.1.5), which catalyses the hydrolysis of urea to $\mathrm{CO}_{2}$ and $\mathrm{NH}_{3}$, was determined according to Kandeler and Gerber (1988). Protease activity was determined spectrophotometrically after the incubation of the soil with sodium caseynate during $2 \mathrm{~h}$ at $50{ }^{\circ} \mathrm{C}$ (Ladd and Butler, 1972; Alef and Nannipieri, 1995). All measurements were carried out in quadruplicate.

\subsubsection{Ecotoxicity bioassays}

Two indirect exposure bioassays were performed: luminescent inhibition of $V$. fischeri (ISO 11348-2, 1998) and $D$. magna immobilization (ISO 6341, 1996). Soil leachate was obtained according to DIN 38 414-S4 (1984), using a batch test with a single leaching cycle (deionised water in a 1:10 (m/v) solid-to-liquid ratio, $24 \mathrm{~h}$ under constant agitation, at room temperature). The leachate was separated by centrifugation, filtered through a membrane filter of pore size $0.45 \mu \mathrm{m}$ and analysed for $\mathrm{pH}, \mathrm{EC}$ and $\mathrm{Cu}, \mathrm{Zn}$ and $\mathrm{Pb}$ contents by flame atomic absorption spectrometry using a Varian apparatus (SpectrAA 220FS).

The $D$. magna acute immobilization test was performed according to the standardised method ISO 6341 (1996). Soil leachates, and their dilutions, $12.5 \%, 25 \%, 50 \%$ and $75 \%(\mathrm{v} / \mathrm{v})$, were tested. Holding and dilution water was prepared according to ISO 6341 (1996) and used also as a negative control. Five young daphnids, aged less than $24 \mathrm{~h}$ at the start of the test, were exposed to $20 \mathrm{~mL}$ of the test solution at different concentrations for a period of $48 \mathrm{~h}$. Tests were conducted in environmental chambers at $20 \pm 2{ }^{\circ} \mathrm{C}$. A $16 \mathrm{~h}$ light and $8 \mathrm{~h}$ dark cycle was used. Immobilization was recorded after 24 and $48 \mathrm{~h}$ exposure and compared with the control.

Inhibitory effects of soil leachate on the light emission of $V$. fischeri (NRRL B-11177) were determined according to ISO 11348-2 (1998). Soil leachates, and their dilutions with a non-toxic control ( $2 \% \mathrm{NaCl}$ solution), 6.25\%, $12.5 \%, 25 \%$ and $50 \%$ (v/v), were tested and compared with the control. The decrease of luminescence was measured after 15 and 30 min contact using a LUMIStox 300 equipment. All measurements were carried out in duplicate. Whenever possible, the $\mathrm{EC}_{20}$ and $\mathrm{EC}_{50}$ values (leachate concentration, $\% \mathrm{v} / \mathrm{v}$, at which a toxic effect on $20 \%$ or $50 \%$ of the population of organisms can be observed) were calculated.

\subsection{Statistical treatment of data}

All data were checked for homogeneity of variance and normality (Kolmogorov-Smirnov test) and, when possible, subjected to one-way ANOVA. Data not satisfying assumptions for ANOVA were analysed non-parametrically using Kruskal-Wallis ANOVA by Ranks test. Whenever significant differences where found $(p<0.05)$ a post-hoc Tukey honest significant difference (HSD) test was used to further elucidate differences among means $(p<0.05)$.

For statistical purposes, results below the detection limit, although reported as "not detected", were assumed to be equal to the detection limit. Pearson correlation coefficients $(r)$ were calculated between soil physico-chemical properties and their enzymatic activities. Three levels of significance were considered: $p<0.05, p<0.01$ and $p<0.001$. All statistical analysis was carried out with the software Statistica 6.0 (StatSoft, Inc., 2001). The $\mathrm{EC}_{20}$ and $\mathrm{EC}_{50}$ values were calculated using the Trimmed Spearman-Karber method (Hamilton et al., 1977).

\section{Results and discussion}

\subsection{Changes in soil chemical properties}

The SS application rates used led to significant increases in $\mathrm{pH}, \mathrm{OM}$ content, CEC, and EC values (Fig. 1a-d) compared with control soil $(p<0.05)$. Comparing the limed and the correspondent 


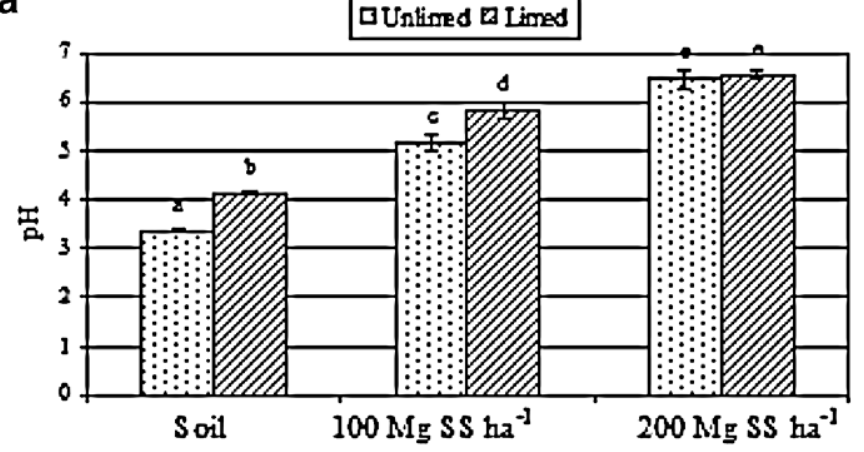

C

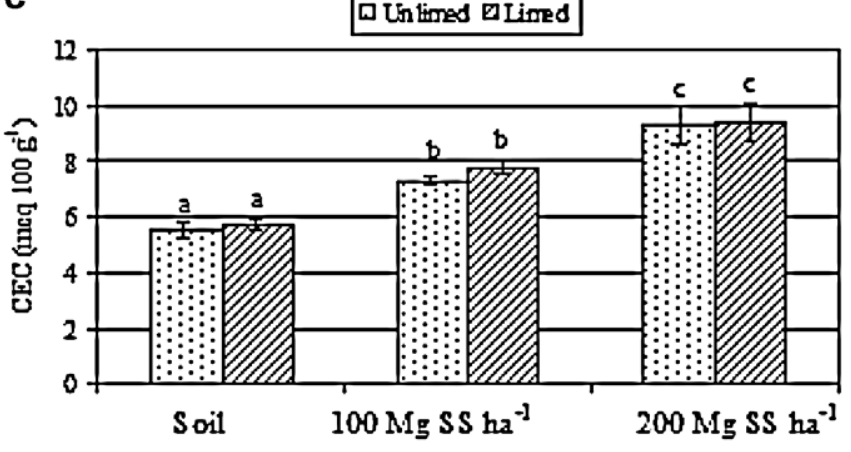

b

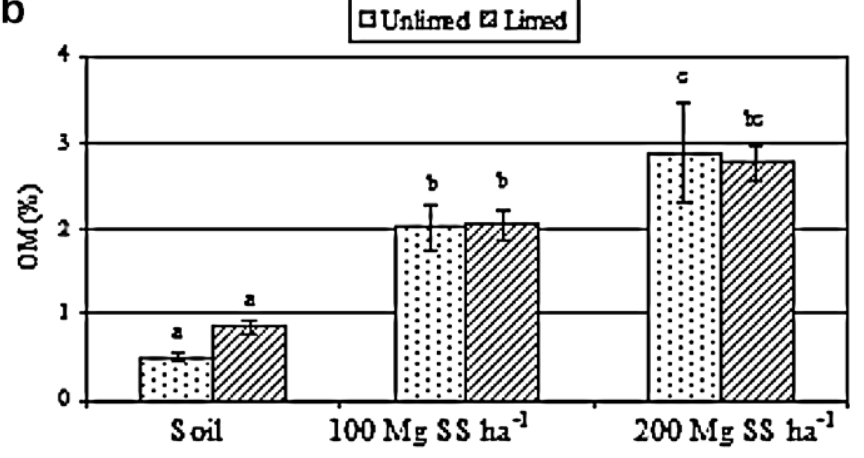

d

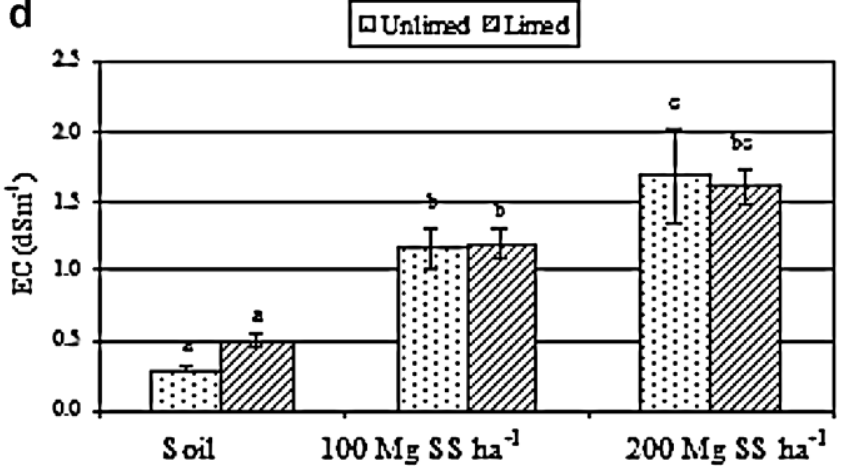

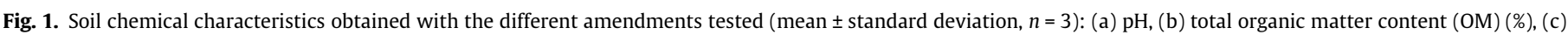

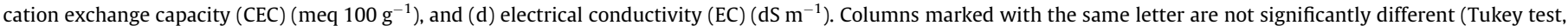
$p>0.05)$. SS: sewage sludge.

unlimed treatment, the values for OM content, CEC and EC were not significantly different between treatments. $\mathrm{pH}$ values close to 6.0-6.5 were obtained by the application of $200 \mathrm{Mg} \mathrm{SS} \mathrm{ha}^{-1}$ (with or without SBS) or with $100 \mathrm{Mg} \mathrm{SS} \mathrm{ha}{ }^{-1}$ plus SBS.

Pseudo-total concentrations of $\mathrm{Cu}, \mathrm{Pb}$ and $\mathrm{Zn}$, did not change significantly with SS or SBS application (data not shown) and, consequently, the heavy metal load into the mine soil from these particular types of sludges and application rates can be neglected.

The application of SBS significantly decreased $\mathrm{Cu}$ and $\mathrm{Zn}$ effective bioavailable fractions, relative to the unamended soil, but the strongest effect was obtained with the addition of SS, that led to levels of effective bioavailable $\mathrm{Cu}$ and $\mathrm{Zn}$ undetected by the analytical technique used (Table 2). These results can be explained by the fact that acidity is one of the most important factors controlling solubility and adsorption-desorption of metals in soils (Ross, 1994; Walker et al., 2003). Consequently, the residues de- creased the effective bioavailability of metals, as they raised soil $\mathrm{pH}$. This could be attributed to the high $\mathrm{CaCO}_{3}$ content of SBS and to the basic cations $\left(\mathrm{Ca}^{2+}, \mathrm{Mg}^{2+}, \mathrm{Na}^{+}\right.$and $\left.\mathrm{K}^{+}\right)$present in the amendments (Pérez-de-Mora et al., 2006). Another important factor controlling metal bioavailability, is the quantity and quality of OM (Ross, 1994). Organic amendments that contain a large proportion of humified OM, can also decrease the bioavailability of heavy metals due to the formation of stable chelates (Walker et al., 2003; Clemente et al., 2006). In fact, the greatest decrease in effective bioavailable $\mathrm{Cu}$ and $\mathrm{Zn}$ was achieved with SS application. On the other hand, $\mathrm{Pb}$ effective bioavailability was already small in the unamended soil and its level was undetected in all treatments with amendments.

Basta and Sloan (1999), among others, reported that the application of organic residues can promote an increase in soil $\mathrm{pH}$, and, as a consequence, can decrease effective metal bioavailability.

Table 2

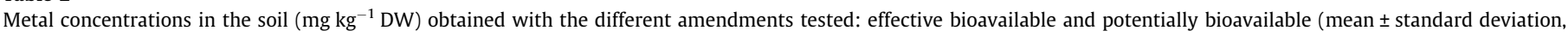
$n=3)$

\begin{tabular}{|c|c|c|c|c|c|c|c|}
\hline & \multicolumn{3}{|l|}{$\mathrm{Cu}\left(\mathrm{mg} \mathrm{kg}^{-1} \mathrm{DW}\right)$} & \multicolumn{2}{|c|}{$\mathrm{Pb}\left(\mathrm{mg} \mathrm{kg}^{-1} \mathrm{DW}\right)$} & \multicolumn{2}{|c|}{$\mathrm{Zn}\left(\mathrm{mg} \mathrm{kg}^{-1} \mathrm{DW}\right)$} \\
\hline & $\begin{array}{l}\text { SS application rate } \\
\left(\mathrm{Mg} \mathrm{ha}^{-1}\right)\end{array}$ & $\begin{array}{l}\text { Effective } \\
\text { bioavailable }^{\mathrm{A}}\end{array}$ & $\begin{array}{l}\text { Potentially } \\
\text { bioavailable }^{\mathrm{B}}\end{array}$ & $\begin{array}{l}\text { Effective } \\
\text { bioavailable }^{\mathrm{A}}\end{array}$ & $\begin{array}{l}\text { Potentially } \\
\text { bioavailable }^{\mathrm{B}}\end{array}$ & $\begin{array}{l}\text { Effective } \\
\text { bioavailable }^{\mathrm{A}}\end{array}$ & $\begin{array}{l}\text { Potentially } \\
\text { bioavailable }^{\mathrm{B}}\end{array}$ \\
\hline Unlimed & $\begin{array}{l}0 \\
100 \\
200\end{array}$ & $\begin{array}{l}3.4 \pm 0.1^{\mathrm{a}} \\
<\mathrm{QL} \\
<\mathrm{QL}\end{array}$ & $\begin{array}{r}7.6 \pm 0.3^{\mathrm{ab}} \\
12.3 \pm 1.7^{\mathrm{bc}} \\
14.6 \pm 1.4^{\mathrm{cd}}\end{array}$ & $\begin{array}{l}<\mathrm{QL} \\
<\mathrm{QL} \\
<\mathrm{QL}\end{array}$ & $\begin{array}{l}21 \pm 2^{\mathrm{ab}} \\
51 \pm 12^{\mathrm{ab}} \\
80 \pm 14^{\mathrm{bc}}\end{array}$ & $\begin{array}{l}5.8 \pm 0.3^{\mathrm{a}} \\
1.4 \pm 0.7^{\mathrm{bc}} \\
<\mathrm{QL}\end{array}$ & $\begin{array}{c}6.8 \pm 0.4^{\mathrm{a}} \\
19.4 \pm 1.6^{\mathrm{ab}} \\
39.3 \pm 11.2^{\mathrm{bc}}\end{array}$ \\
\hline Limed & $\begin{array}{l}0 \\
100 \\
200\end{array}$ & $\begin{array}{l}0.6 \pm 0.1^{\mathrm{b}} \\
<\mathrm{QL} \\
<\mathrm{QL}\end{array}$ & $\begin{array}{c}5.5 \pm 0.4^{\mathrm{a}} \\
13.5 \pm 0.7^{\mathrm{c}} \\
13.7 \pm 1.9^{\mathrm{cd}}\end{array}$ & $\begin{array}{l}<\mathrm{QL} \\
<\mathrm{QL} \\
<\mathrm{QL}\end{array}$ & $\begin{array}{l}20 \pm 2^{\mathrm{a}} \\
50 \pm 2^{\mathrm{ab}} \\
65 \pm 8^{\mathrm{ab}}\end{array}$ & $\begin{array}{l}2.2 \pm 0.6^{\mathrm{b}} \\
0.5 \pm 0.1^{\mathrm{c}} \\
<\mathrm{QL}\end{array}$ & $\begin{array}{c}4.0 \pm 0.5^{\mathrm{a}} \\
20.3 \pm 2.0^{\mathrm{ab}} \\
48.6 \pm 19.3^{\mathrm{c}}\end{array}$ \\
\hline
\end{tabular}

QL: quantification limit; DW: dry weight; QL $(\mathrm{Cu})=0.5 \mathrm{mg} \mathrm{kg}^{-1} \mathrm{DW} ; \mathrm{QL}(\mathrm{Pb})=5.0 \mathrm{mg} \mathrm{kg}^{-1} \mathrm{DW} ; \mathrm{QL}(\mathrm{Zn})=0.5 \mathrm{mg} \mathrm{kg}{ }^{-1} \mathrm{DW}$.

Means within each column marked with the same letter are not significantly different (Tukey HSD test, $p>0.05$ ).

A Extracted by $0.01 \mathrm{M}$ calcium chloride solution.

B Extracted by $0.5 \mathrm{M}$ ammonium acetate, $0.5 \mathrm{M}$ acetic acid and 0.01 M EDTA, pH 4.7. 
However, they can also be responsible for large metal loadings into the soil. The potential risk derived from their application can be estimated from the potential bioavailable metal fraction (Table 2 ). In the present experiment, the SBS did not contribute to an increase in potentially bioavailable $\mathrm{Cu}, \mathrm{Pb}$ and $\mathrm{Zn}$, but the application of SS caused a significant increase in their values. Hence, although SS application was in accordance with sustainable management practices, it has to be applied at the right rates and the soil should be monitored regularly.

\subsection{Changes in soil enzymatic activities}

Both $\beta$-glucosidase and cellulase are extracelular enzymes related to the C-cycle, with an important role in OM degradation: cellulases are enzyme systems that degrade cellulose and release reducing sugars as the end product, and $\beta$-glucosidase is involved in the final step of cellulose degradation, catalysing the hydrolysis of carbohydrates with $\beta$-D-glucoside bonds like cellobiose, providing energy substrates for soil heterotrophic microorganisms (Tabatabai, 1982; Eivazi and Tabatabai, 1988). $\beta$-Glucosidase has been widely used to assess soil quality. It is usually impaired by agronomic practices that cause a rapid loss of soil OM (e.g. tillage), and enhanced following application of organic amendments (Gil-Sotres et al., 2005; Pérez-de-Mora et al., 2005). Some authors reported that $\beta$-glucosidase activity is strongly reduced by the presence of heavy metals (Hinojosa et al., 2004a), but Pérez-deMora et al. (2005) suggested that the major factor that influences its activity is soil OM. In the present study, both factors could have positively influenced $\beta$-glucosidase activity, which increased with increasing SS applications rates (Fig. 2a): an increase in soil OM content and a concomitant decrease in metal effective bioavailability. For cellulase, the only treatments where a significantly higher activity was found, compared with unamended soil, were those with $100 \mathrm{Mg} \mathrm{ha}^{-1} \mathrm{SS}$, with or without liming (Fig. 2c). The greatest SS application rate tested ( $200 \mathrm{Mg} \mathrm{ha}^{-1}$ ) led to adverse conditions for this enzyme, as for other parameters, as discussed below.

Acid phosphomonoestearase (acid phosphatase) is one of the many phosphatases in soils and it is largely responsible for the mineralization of organic phosphate compounds in acid soils (Eivazi and Tabatabai, 1977; Huang and Shindo, 2000). Among
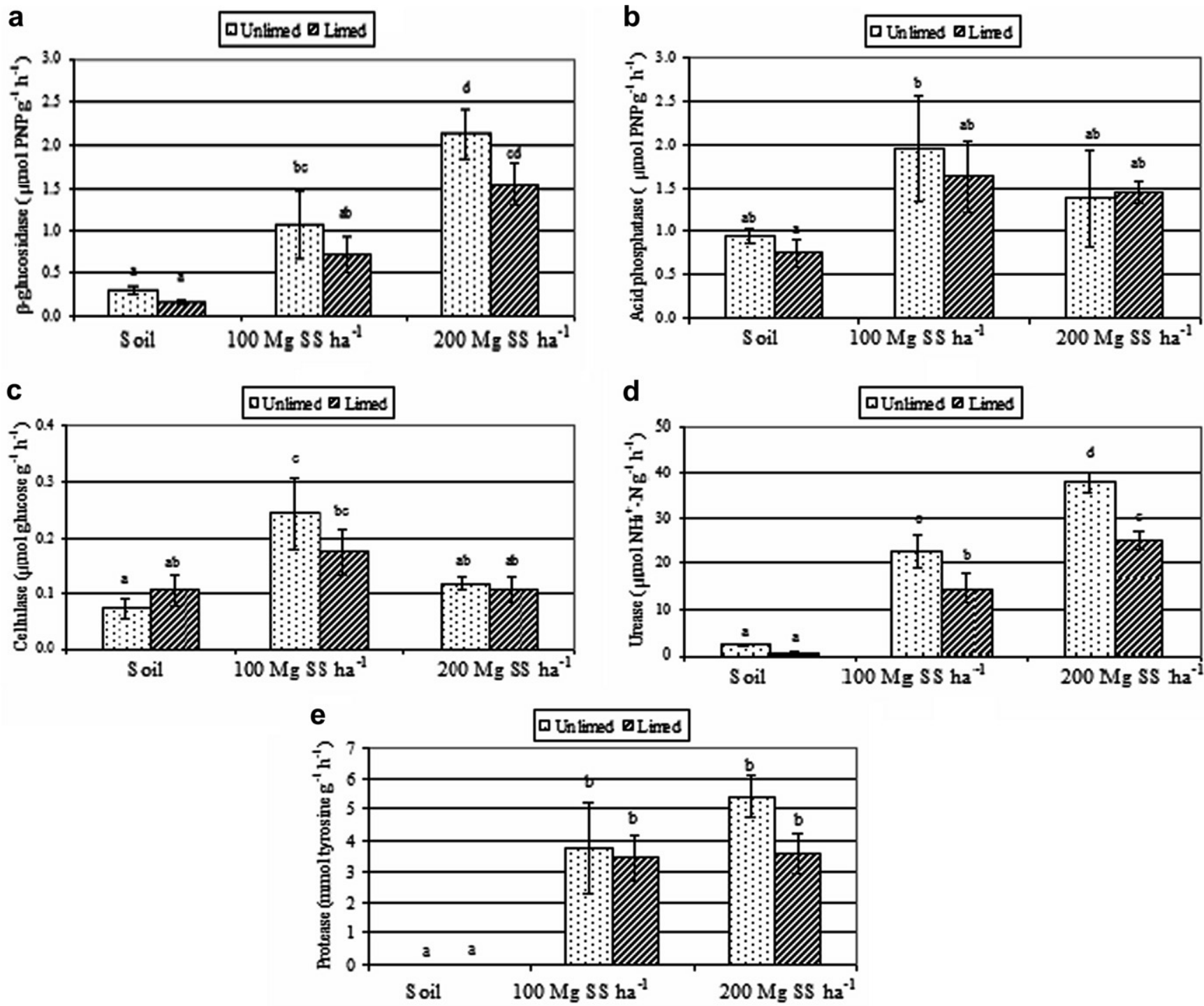

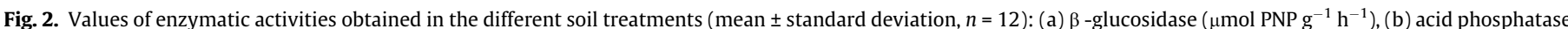

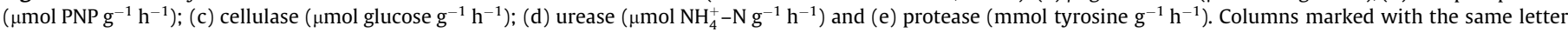
are not significantly different (Tukey HSD test, $p>0.05$ ). PNP: $p$-nitrophenol; SS: sewage sludge. 
Table 3

Pearson's correlation coefficients between soil chemical properties and their enzymatic activities $(n=18)$

\begin{tabular}{|c|c|c|c|c|c|c|c|c|c|c|c|c|c|c|}
\hline & $\mathrm{pH}$ & EC & OM & CEC & $\mathrm{Cu}(\mathrm{EB})$ & $\mathrm{Cu}(\mathrm{PB})$ & $\mathrm{Pb}(\mathrm{T})$ & $\mathrm{Pb}(\mathrm{PB})$ & $\mathrm{Zn}(\mathrm{EB})$ & $\mathrm{Zn}(\mathrm{PB})$ & $\beta$-gluc & Ac-phos & Cellu & Prot \\
\hline $\mathrm{EC}$ & $0.95^{* * *}$ & - & - & - & - & - & - & - & - & - & - & - & - & - \\
\hline OM & $0.95_{* * * *}^{* * *}$ & $1^{* * *} \quad * * *$ & - $\quad * * *$ & - & - & - & - & - & - & - & - & - & - & - \\
\hline CEC & $0.88_{* * * *}^{* * *}$ & $0.81_{* * * *}^{* * *}$ & $0.81_{* * * *}^{* * *}$ & - & - & - & - & - & - & - & - & - & - & - \\
\hline $\mathrm{Cu}(\mathrm{EB})$ & $-0.79^{* * *}$ & $-0.74^{* * *}$ & $-0.74^{* * *}$ & $-0.50^{*}$ & - & - & - & - & - & - & - & - & - & - \\
\hline $\mathrm{Cu}(\mathrm{PB})$ & $0.87_{* * *}^{* * *}$ & $0.86_{*}^{* * *}$ & $0.86_{*}^{* * *}$ & $0.70_{* *}^{* *}$ & $-0.55^{*}$ & - & - & - & - & - & - & - & - & - \\
\hline $\mathrm{Pb}(\mathrm{T})$ & $0.52^{*}$ & $0.51^{*}$ & $0.51^{*}$ & $0.47^{*}$ & -0.39 & 0.43 & - & - & - & - & - & - & - & - \\
\hline $\mathrm{Pb}(\mathrm{PB})$ & $0.89^{* * *}$ & $0.96^{* * *}$ & $0.96^{* * *}$ & $0.79^{* * *}$ & $-0.61^{* *}$ & $0.86^{* * *}$ & $0.48^{*}$ & - & - & - & - & - & - & - \\
\hline $\mathrm{Zn}(\mathrm{EB})$ & $-0.92^{* * * *}$ & $-0.87^{* * * *}$ & $-0.87^{* * *}$ & $-0.72^{* * * *}$ & $0.95^{* * *}$ & $-0.69^{* *}$ & $-0.47^{*}$ & $-0.77^{* * *}$ & - & - & - & - & - & - \\
\hline $\mathrm{Zn}(\mathrm{PB})$ & $0.82^{* * * *}$ & $0.77^{* * *}$ & $0.77^{* * *}$ & $0.86^{* * * *}$ & $-0.49^{*}$ & $0.70^{* *}$ & 0.23 & $0.72^{* * * *}$ & $-0.65^{* *}$ & - & - & - & - & - \\
\hline$\beta$-gluc & $0.83_{* *}^{* * *}$ & $0.86^{* * * *}$ & $0.86_{*}^{* * *}$ & $0.77^{* * *}$ & $-0.51^{*}$ & $0.77_{* *}^{* * *}$ & 0.26 & $0.89^{* * * *}$ & $-0.68^{* *}$ & $0.85^{* * *}$ & & _ & _ & - \\
\hline Ac-phos & $0.48^{* *}$ & $0.52^{*}$ & $0.52^{*}$ & 0.18 & $-0.43_{*}$ & $0.65^{* *}$ & 0.14 & $0.51^{*}$ & -0.47 & 0.37 & $0.49^{*}$ & - & - & - \\
\hline Cellu & 0.24 & 0.29 & 0.29 & -0.16 & $-0.48^{*}$ & 0.35 & 0.17 & 0.30 & -0.38 & -0.01 & 0.14 & $\overline{0} .77$ & - & - \\
\hline Prot & $0.88^{* * *}$ & $0.91^{* * * *}$ & $0.91_{* * * *}^{* * *}$ & $0.69^{* *}$ & $-0.67^{* *}$ & $0.89^{* * * *}$ & 0.38 & $0.92^{* * * *}$ & $-0.79^{* * * *}$ & $0.74^{* * * *}$ & $0.89^{* * * *}$ & $0.69^{* *}$ & $\overline{0} .47^{*}$ & - \\
\hline Ure & $0.86^{* * *}$ & $0.91^{* * *}$ & $0.91^{* * *}$ & $0.72^{* *}$ & $-0.60^{* *}$ & $0.87^{* * *}$ & 0.34 & $0.94^{* * *}$ & $-0.73^{* * *}$ & $0.76^{* * *}$ & $0.96^{* * *}$ & $0.56^{*}$ & 0.30 & $0.94^{* * *}$ \\
\hline
\end{tabular}

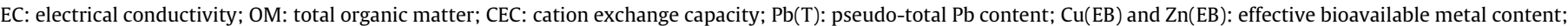

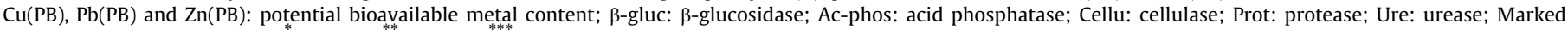
correlations are significant at: $p<0.05 ; \quad p<0.01 ; \quad p<0.001$.

hydrolases, acid phosphomonoesterase activity has been frequently used to estimate changes in soil quality, due to management practices or presence of contaminants (Gil-Sotres et al., 2005). Its activity is impaired by $\mathrm{Pb}$ (Gil-Sotres et al., 2005) and other heavy metals, such as $\mathrm{Cd}, \mathrm{Zn}$ and $\mathrm{Cu}$ (Renella et al., 2003). As it is considered a good index of the quality and quantity of $\mathrm{OM}$ in soils, it was predicted that if the OM content of a degraded soil were to increase, this enzymatic activity should also rise. However, in the present experiment, the activity of acid phosphatase was not affected by the treatments (Fig. 2b), with no significant differences between its activities in the different pots. Likely, the level of heavy metals was still too high, impairing its activity, or the raise in soil $\mathrm{pH}$ did not had a positive effect on its activity.

Protease is the enzyme that catalyses protein hydrolysis to peptides and aminoacids (Ladd and Butler, 1972; Alef and Nannipieri, 1995), and urease is the enzyme that catalyses the hydrolysis of urea to $\mathrm{CO}_{2}$ and $\mathrm{NH}_{3}$ (Kandeler and Gerber, 1988). The activity of both enzymes, related to the N-cycle, increased compared to the unamended soil following the application of SS (although with no significant differences between the four amended treatments in the case of protease) (Fig. 2d and e). Moreover, comparing the relative increase in all enzymatic activities, these two enzymes had the highest positive response to soil amendments. This could be a consequence of the fact that the SS used had a high organic nitrogen content, $7.2 \%$ DW (Table 1 ), which improved the activity of enzymes related to the $\mathrm{N}$-cycle.

Significant differences between the unlimed and the limed SS treated pots were found only in the case of the urease activity, with smaller activities when SBS was applied. In fact, although with no significant differences, liming with SBS seems to have contributed to a decrease in the activity of all the enzymes tested.

\subsection{Pearson's correlations}

Table 3 shows the Pearson's correlation coefficients between soil chemical properties and their enzymatic activities. In general, chemical parameters ( $\mathrm{pH}, \mathrm{EC}, \mathrm{OM}$ and $\mathrm{CEC}$ ) and potentially bioavailable $\mathrm{Cu}, \mathrm{Pb}$ and $\mathrm{Zn}$ were highly positively correlated with each other $(p<0.001)$. This was predictable, as the application of SBS and SS promoted an increase in these soil properties. In contrast, negative correlations were found between effective bioavailable $\mathrm{Cu}$ and effective bioavailable $\mathrm{Zn}$ and the chemical parameters. Pseudo-total contents of $\mathrm{Cu}$ and $\mathrm{Zn}$ and effective bioavailable $\mathrm{Pb}$ were not correlated with any other soil properties (data not shown). With the exception of cellulase, all soil enzymatic activities were positively correlated with soil chemical properties, and negatively correlated with effective bioavailable $\mathrm{Cu}$ and $\mathrm{Zn}$. Other authors, studying the potential use of soil enzymes as indicators of changes in soil microbial activity in response to heavy metals and remedial measures, reported similar results (Huang and Shindo, 2000; Kızılkaya et al., 2004; Hinojosa et al., 2004a,b; Pérez-deMora et al., 2005, 2006). Enzyme reactions are inhibited by metals which may complex with the substrate, combine with the active site of enzymes, or react with the enzyme-substrate complex (Hinojosa et al., 2004a). However, high levels of heavy metals are not always translated into lower enzymatic activities for all soil enzymes. Examples were reported by Hinojosa et al. (2004b), who found that arylsulfatase and alkaline phosphatase activities were similar in polluted and restored soils and by Kizılkaya et al. (2004), who found that urease activity was not negatively correlated with total heavy metal content in agricultural soils. Aoyama et al. (1993) also reported that $\beta$-glucosidase was only marginally affected by high $\mathrm{Cu}$ and $\mathrm{Zn}$ concentrations. According to Hinojosa et al. (2004a), soil type (e.g. CEC, OM content) modulates the nature and degree of inhibition of soil enzymes by heavy metals, explaining the referred contradictions. Kizılkaya et al. (2004) stated that extracellular enzymes, like urease, which is strongly adsorbed by clay and humus, are more resistant to environmental impacts than other enzymes and their activities (e.g. dehydrogenase and catalase).

\subsection{Plant analysis}

Plant biomass increased more than 10 times in the presence of $100 \mathrm{Mg} \mathrm{SS} \mathrm{ha}{ }^{-1}$, and more than five times with the combined use of $100 \mathrm{Mg} \mathrm{SS} \mathrm{ha}^{-1}$ and SBS (data not shown). A considerable phytotoxic effect was registered for the $200 \mathrm{Mg} \mathrm{SS} \mathrm{ha}^{-1}$ application rate,

Table 4

Metal concentrations ( $\mathrm{mg} \mathrm{kg}^{-1} \mathrm{DW}$ ) in the aboveground plant material of $\mathrm{L}$. multiflorum (mean \pm standard deviation, $n=3$ )

\begin{tabular}{lllll}
\hline & $\begin{array}{l}\text { SS application rate } \\
\left(\mathrm{Mg} \mathrm{ha}^{-1}\right)\end{array}$ & $\begin{array}{l}\mathrm{Cu} \\
\left(\mathrm{mg} \mathrm{kg}^{-1} \mathrm{DW}\right)\end{array}$ & $\begin{array}{l}\mathrm{Pb} \\
\left(\mathrm{mg} \mathrm{kg}^{-1} \mathrm{DW}\right)\end{array}$ & $\begin{array}{l}\mathrm{Zn} \\
\left(\mathrm{mg} \mathrm{kg}^{-1} \mathrm{DW}\right)\end{array}$ \\
\hline Unlimed & 0 & $63.3 \pm 0.2^{\mathrm{a}}$ & $41 \pm 7^{\mathrm{a}}$ & $499 \pm 35^{\mathrm{a}}$ \\
& 100 & $11.5 \pm 0.9^{\mathrm{b}}$ & $<\mathrm{QL}$ & $26 \pm 1^{\mathrm{b}}$ \\
Limed & 0 & $5.9 \pm 0.5^{\mathrm{b}}$ & $<\mathrm{QL}$ & $27 \pm 4^{\mathrm{b}}$ \\
& 100 & $16 \pm 2^{\mathrm{b}}$ & $23 \pm 4^{\mathrm{a}}$ & $27 \pm 3^{\mathrm{b}}$ \\
\hline
\end{tabular}

Means within each column marked with the same superscript letter are not significantly different (Tukey HSD test, $p>0.05$ ).

SS: sewage sludge; DW: dry weight; QL: quantification limit; $\mathrm{QL}(\mathrm{Pb})=5.0 \mathrm{mg} \mathrm{kg}{ }^{-1}$ DW. 
Table 5

Results from the acute toxicity bioassays using soil leachates $\left(\mathrm{EC}_{\mathrm{xx}} \pm\right.$ standard deviation, $\left.n=6\right)$

\begin{tabular}{|c|c|c|c|c|c|c|c|}
\hline & \multicolumn{5}{|c|}{ Luminescent inhibition (V. fischeri) \% (v/v) } & \multicolumn{2}{|c|}{ Immobilization $(48 \mathrm{~h})($ D. magna) \% (v/v) } \\
\hline & \multirow[t]{2}{*}{ SS application rate $\left(\mathrm{Mg} \mathrm{ha}^{-1}\right)$} & \multicolumn{2}{|l|}{$15 \min$} & \multicolumn{2}{|l|}{$30 \mathrm{~min}$} & \multirow[t]{2}{*}{$\mathrm{EC}_{20}$} & \multirow[t]{2}{*}{$\mathrm{EC}_{50}$} \\
\hline & & $\mathrm{EC}_{20}$ & $\mathrm{EC}_{50}$ & $\mathrm{EC}_{20}$ & $\mathrm{EC}_{50}$ & & \\
\hline Unlimed & $\begin{array}{l}0 \\
100 \\
200\end{array}$ & $\begin{array}{l}\text { n.t. } \\
22.0 \pm 0.3 \\
15.8 \pm 0.2\end{array}$ & $\begin{array}{l}\text { n.t. } \\
\text { n.t. } \\
47.0 \pm 0.2\end{array}$ & $\begin{array}{l}\text { n.t. } \\
5.0 \pm 0.3 \\
16.3 \pm 0.1\end{array}$ & $\begin{array}{l}\text { n.t. } \\
\text { n.t. } \\
45.5 \pm 0.1\end{array}$ & $\begin{array}{l}20 \pm 3 \\
\text { n.t. } \\
\text { n.t. }\end{array}$ & $\begin{array}{l}31 \pm 2 \\
\text { n.t. } \\
\text { n.t. }\end{array}$ \\
\hline Limed & $\begin{array}{l}0 \\
100 \\
200\end{array}$ & $\begin{array}{l}\text { n.t. } \\
\text { n.t. } \\
21.0 \pm 0.2\end{array}$ & $\begin{array}{l}\text { n.t. } \\
\text { n.t. } \\
62.0 \pm 0.2\end{array}$ & $\begin{array}{l}50.5 \pm 0.1 \\
\text { n.t. } \\
22.7 \pm 0.3\end{array}$ & $\begin{array}{l}\text { n.t. } \\
\text { n.t. } \\
63.8 \pm 0.2\end{array}$ & $\begin{array}{l}\text { n.t. } \\
\text { n.t. } \\
\text { n.t. }\end{array}$ & $\begin{array}{l}\text { n.t. } \\
\text { n.t. } \\
\text { n.t. }\end{array}$ \\
\hline
\end{tabular}

n.t.: no toxic effect detected; SS: sewage sludge.

$\mathrm{EC}_{20}$ : leachate concentration (\% v/v) at which a toxic effect on $20 \%$ of the exposed organism can be observed, considering the selected endpoint.

$\mathrm{EC}_{50}$ : leachate concentration $(\% \mathrm{v} / \mathrm{v})$ at which a toxic effect on $50 \%$ of the exposed organism can be observed, considering the selected endpoint

with no plant growth in these pots. This probably derived from soluble salts present in the sludge, rather than to the presence of heavy metals that, as discussed above, were less bioavailable following soil amendment. The same explanation was put forward by Rodgers and Anderson (1995), who recommended that sludge amendments should not exceed a one-time application of $100 \mathrm{Mg} \mathrm{ha}^{-1}$ to prevent growth inhibition during the first year, following field application. Ye et al. (2002) pointed out that at an EC of $4 \mathrm{dS} \mathrm{m}^{-1}$, yield of many crops will be restricted due to inhibition of plant growth and seed germination.

Copper, $\mathrm{Pb}$ and $\mathrm{Zn}$ concentrations in the shoots of $L$. multiflorum decreased significantly using $100 \mathrm{Mg} \mathrm{SS} \mathrm{ha} \mathrm{M}^{-1}$ or SBS, but liming the SS-amended soil with SBS did not contribute to a further reduction in the level of these metals in the plant (Table 4).

\subsection{Bioassays results}

The leachate from the unamended soil, at the end of the experiment, was toxic to D. magna but not to $V$. fischeri (Table 5 ). As the original mine soil presented toxicity towards $V$. fischeri, $\mathrm{EC}_{20}$ $(15 \mathrm{~min})$ of $45.2 \%$ and $\mathrm{EC}_{20}$ (30 min) of $10.7 \%(\mathrm{v} / \mathrm{v})$ (Alvarenga et al., 2008), the decreased toxicity of the unamended soil towards $V$. fischeri can only be ascribed to its vegetation cover.

Both amendments were able to suppress soil toxicity to levels that did not affect $D$. magna, but increased the toxicity towards $V$. fischeri, especially with the application of $200 \mathrm{Mg} \mathrm{SS} \mathrm{ha}^{-1}$. This result corroborates the phytotoxicity results discussed above: $200 \mathrm{Mg} \mathrm{SS} \mathrm{ha}{ }^{-1}$ was excessive, resulting in toxicity towards some organisms.

As pointed out by other authors, no single bioassay is sufficient to monitor a remediation process, since toxicity trends during remediation differ according to the assay used (Knoke et al., 1999). In this study, we found that $V$. fischeri was extremely sensitive to high doses of SS applied to soil. Chaîneau et al. (2003) also found that $V$. fischeri and plant growth were very sensitive indicators of soil toxicity, and were more reliable than other bioassays (e.g. worm survival and seed germination).

\section{Conclusions}

The amendments used had positive effects on the soil chemical properties. The SS used, in particular when in combination with SBS, was able to correct soil acidity, while increasing the soil total OM content and its CEC. In particular, SS proved to be very efficient in raising soil $\mathrm{pH}$, decreasing effective bioavailable heavy metals, so that liming was not needed for the SS higher application rate (200 $\left.\mathrm{Mg} \mathrm{ha}^{-1}\right)$. However, concomitantly, all amendments led to a significant increase in EC values, which, in some cases, were phytotoxic.
The highest SS application rate should be $100 \mathrm{Mg} \mathrm{ha}^{-1}$, as a higher application rate (200 Mg SS ha ${ }^{-1}$ ) was toxic to plants and $V$. fischeri and led to a lower soil cellulase activity. Liming the SSamended soil with SBS did not contribute to a further improvement in soil quality, as evaluated by its bioavailable metal content and by its enzymatic activities.

This study showed that the application of SS, at a rate of $100 \mathrm{Mg} \mathrm{ha}^{-1}$, improved the quality of the mine soil, as evaluated by the combined use of chemical, biochemical and ecotoxicological parameters. More studies are needed to separate the effects of amendment application from the effects of a vegetation cover on soil characteristics, especially in soil effective bioavailable heavy metals, and in soil biochemical and ecotoxicological properties.

\section{Acknowledgement}

This study was supported by project PPCDT/AMB/57586/2004 from "Fundação para a Ciência e Tecnologia".

\section{References}

Alef, K., Nannipieri, P., 1995. Protease activity. In: Alef, K., Nannipieri, P. (Eds.), Methods in Applied Soil Microbiology and Biochemistry. Academic Press, London, pp. 313-315.

Alvarenga, P. Palma, P. Gonçalves, A.P., Fernandes, R.M., Cunha-Queda, A.C., Duarte, E., Vallini, G., 2007. Evaluation of chemical and ecotoxicological characteristics of biodegradable organic residues for application to agricultural land. Environ. Int. 33, 505-513.

Alvarenga, P., Palma, P., Gonçalves, A.P., Fernandes, R.M., de Varennes, A., Vallini, G. Duarte, E., Cunha-Queda, A.C., 2008. Evaluation of tests to assess the quality of mine contaminated soils. Environ. Geochem. Health 30, 95-99.

Aoyama, M., UItaya, S., Otawa, M., 1993. Effects of copper on the decomposition of plant residues, microbial biomass, and $\beta$-glucosidase in soils. Soil Sci. Plant Nutr. 39, 557-566.

Basta, N.T., Sloan, J.J., 1999. Bioavailability of heavy metals in strongly acidic soils treated with exceptional quality biosolids. J. Environ. Qual. 28, 633-638.

Basta, N.T., Gradwohl, R., Snethen, K.L., Schroder, J.L., 2001. Chemical immobilization of lead, zinc, and cadmium in smelter-contaminated soils using biosolids and rock phosphate. J. Environ. Qual. 30, 1222-1230.

Brown, S.L., Chaney, R.L., Hallfrisch, J., Xue, Q., 2003. Effect of biosolids processing on lead bioavailability in an urban soil. J. Environ. Qual. 32, 100-108.

Brown, S.L., Sprenger, M., Maxemchuk, A., Compton, H., 2005. Ecosystem function in alluvial tailings after biosolids and lime application. J. Environ. Qual. 34, 1-6.

Chaîneau, C.H., Yepremian, C., Vidalie, J.F., Ducreaux, J., Ballerini, D., 2003. Bioremediation of a crude oil-polluted sol: biodegradation, leaching and toxicity assessments. Water Air Soil Poll. 144, 419-440.

Clemente, R., Escolar, Á., Bernal, M.P., 2006. Heavy metals fractionation and organic matter mineralisation in contaminated calcareous soil amended with organic materials. Bioresour. Technol. 97, 1894-1901.

Conder, J.M., Lanno, R.P., Basta, N.T., 2001. Assessment of metal availability in smelter soil using earthworms and chemical extractions. J. Environ. Qual. 30, 1231-1237.

Decreto-Lei n 118/2006, de 21 de Junho. Diário da República n 118/2006 - I Série A. Ministério do Ambiente, do Ordenamento do Território e do Desenvolvimento Regional, Lisboa.

DIN 38 414-S4, 1984. Determination of Leachability by Water (S4). German Standard Methods for the Examination of Water, Waste Water and Sludge. Sludge and Sediments (group S). Method DIN 38 414-S4. 
Eivazi, F., Tabatabai, M.A., 1977. Phosphatases in soils. Soil Biol. Biochem. 9, 167-172. Eivazi, F., Tabatabai, M.A., 1988. Glucosidases and galactosidases in soils. Soil Biol. Biochem. 20, 601-606.

Gee, G.W., Bauder, J.W., 1986. Particle-size analysis. In: Klute, A. (Ed.), Methods of Soil Analysis. Part 1. Physical and Mineralogical Methods. Soil Science Society of America, Madison, WI, USA, pp. 383-412.

Gil-Sotres, F., Trasar-Cepeda, C., Leirós, M.C., Seoane, S., 2005. Different approaches to evaluating soil quality using biochemical properties. Soil Biol. Biochem. 37, 877-887.

Hamilton, M.A., Russo, R.C., Thurston, R.V., 1977. Trimmed Spearman-Karber Method for estimating median lethal concentrations in toxicity bioassays. Environ. Sci. Technol. 11, 714-719.

Hinojosa, M.B., Carreira, J.A., García-Ruíz, R., Dick, R.P., 2004a. Soil moisture pretreatment effects on enzyme activities as indicators of heavy metalcontaminated and reclaimed soils. Soil Biol. Biochem. 36, 1559-1568.

Hinojosa, M.B., García-Ruíz, R., Viñegla, B., Carreira, J.A., 2004b. Microbiological rates and enzyme activities as indicators of functionality in soils affected by the Aznalcóllar toxic spill. Soil Biol. Biochem. 36, 1637-1644.

Hope, C.F.A., Burns, R.G., 1987. Activity, origins and location of cellulase in a silt loam soil. Biol. Fert. Soils 5, 164-170.

Huang, Q., Shindo, H., 2000. Effects of copper on the activity and kinetics of free and immobilized acid phosphatase. Soil Biol. Biochem. 32, 1885-1892.

ISO 6341, 1996. Water Quality - Determination of Long Term Toxicity of Substances to Daphnia magna Straus (Cladocera, Crustacea) - Acute Toxicity Test. International Organisation for Standardisation, Geneva, Switzerland.

ISO 11348-2, 1998. Water Quality - Determination of the Inhibitory Effect of Water Samples on the Light Emission of Vibrio fischeri (Luminescent Bacteria Test). Part 2: Method Using Liquid-Dried Bacteria. International Organisation for Standardisation, Geneva, Switzerland.

ISO 11466, 1995. Soil Quality - Extraction of Trace Elements Soluble in Aqua Regia International Organisation for Standardisation, Geneva, Switzerland.

ISO/DIS 17402, 2006. Soil Quality - Guidance for the Selection and Application of Methods for the Assessment of Bioavailability in Soil and Soil Materials (Draft Document). International Organization for Standardization, Geneva, Switzerland.

Kandeler, E., Gerber, H., 1988. Short-term assay of soil urease activity using colorimetric determination of ammonium. Biol. Fert. Soils 6, 68-72.

Kızılkaya, R., Askin, T., Bayrakli, B., Saglam, M., 2004. Microbiological characteristics of soils contaminated with heavy metals. Eur. J. Soil Biol. 40, 95-102.

Knoke, K.L., Marwood, T.M., Cassidy, M.B., Liu, D., Seech, A.G., Lee, H., Trevors, J.T. 1999. A comparison of five bioassays to monitor toxicity during bioremediation of pentachlorophenol-contaminated soil. Water Air Soil Pollut. 110, 157-169.

Ladd, J.N., Butler, J.H.A., 1972. Short-term assays of soil proteolytic enzyme activities using proteins and dipeptide derivatives as substrates. Soil Biol. Biochem. 4, 1930 .

Loureiro, S., Ferreira, A.L.G., Soares, A.M.V.M., Nogueira, A.J.A., 2005. Evaluation of the toxicity of two soils from Jales Mine (Portugal) using aquatic bioassays. Chemosphere 61, 168-177.
Matos, J.X., Martins, L.P., 2006. Reabilitação ambiental de áreas mineiras do sector português da Faixa Piritosa Ibérica: estado da arte e perspectivas futuras. Bol. Geol. Minero 117, 289-304.

Pérez-de-Mora, A., Ortega-Calvo, J.J., Cabrera, F., Madejón, E., 2005. Changes in enzyme activities and microbial biomass after "in situ" remediation of heavy metal-contaminated soil. Appl. Soil Ecol. 28, 125-137.

Pérez-de-Mora, A., Burgos, P., Madejón, E., Cabrera, F., Jaeckel, P., Schloter, M., 2006. Microbial community structure and function in a soil contaminated by heavy metals: effects of plant growth and different amendments. Soil Biol. Biochem. 38, 327-341.

Renella, G., Ortigoza, A.L.R., Landi, L., Nannipieri, P., 2003. Additive effects of copper and zinc on cadmium toxicity on phosphatase activities and ATP content of soil as estimated by the ecological dose $\left(\mathrm{ED}_{50}\right)$. Soil Biol. Biochem. 35, 1203 1210

Riehm, H., 1958. Die ammoniumlaktatessigsaure-methode zur bestimmung der leichtloeslichen phosphosaure in karbonathaltigen boden. Agrochimica 3, 4965.

Rodgers, C.S., Anderson, R.C., 1995. Plant growth inhibition by soluble salts in sewage sludge-amended mine spoils. J. Environ. Qual. 24, 627-630.

Ross, S.M., 1994. Retention, transformation and mobility of toxic metals in soils. In: Ross, S.M. (Ed.), Toxic Metals in Soil-Plant Systems. John Wiley \& Sons, Chichester, pp. 63-153.

StatSoft, Inc., 2001. STATISTICA 6.0 - Data Analysis Software System. www.statsoft.com.

Sumner, M.E., Miller, W.P., 1996. Cation exchange capacity and exchange coefficients. In: Bartels, J.M. (Ed.), Methods of Soil Analysis. Part 3. Chemical Methods. Soil Science Society of America, Madison, WI, pp. 1201-1230.

Tabatabai, M.A., 1982. Soil enzymes. In: Page, A.L., Baker, D.E., Rosco, E., Ellis, Jr., Keeney, D.R., Miller, R.H., Rhoades, J.D. (Eds.), Methods of Soil Analysis, Part 2, Chemical and Microbiological Properties. American Society of Agronomy, Inc and Soil Science Society of America, Madison, pp. 903-947.

van Gestel, C.A.M., van der Waarde, J.J., Derksen, J.G.M., van der Hoek, E.E., Veul, M.F.X.W., Bouwens, S., Rusch, B., Kronenburg, R., Stokman, G.N.M., 2001. The use of acute and chronic bioassays to determine the ecological risk and bioremediation efficiency of oil-polluted soils. Environ. Toxicol. Chem. 20, 1438-1449.

Vangronsveld, J., Assche, F.V., Clijsters, H., 1995. Reclamation of a bare industrial area contaminated by non-ferrous metals: in situ metal immobilization and revegetation. Environ. Pollut. 87, 51-59.

Walker, D.J., Clemente, R., Roig, A., Bernal, M.P., 2003. The effects of soil amendments on heavy metal bioavailability in two contaminated Mediterranean soils. Environ. Pollut. 122, 303-312.

Walkley, A., Black, J.A., 1934. An examination of the Degtjareff method for determining soil organic matter and a proposed modification of the chromic acid titration method. Soil Sci. 37, 29-38.

Ye, Z.H., Shu, W.S., Zhang, Z.Q., Lan, C.Y., Wong, M.H., 2002. Evaluation of major constraints to revegetation of lead/zinc mine tailings using bioassay techniques. Chemosphere 47, 1103-1111. 